\title{
Succession of the Plant Communities of the Ustyurt Eastern Cliff (Republic of Uzbekistan) in Connection with Climate Change
}

\author{
Adilov Bekhzod ${ }^{*}$, Rakhimova Tashkhonim ${ }^{1}$, Shomurodov Khabibullo1, \\ Rakhimova Nodira ${ }^{1}$, Vokhidov Yusuf ${ }^{2}$ \\ ${ }^{1}$ Institute of Botany, AS RUz, Tashkent, Uzbekistan \\ ${ }^{2}$ Unitary Enterprise “Geoinform Cadastre”, Tashkent, Uzbekistan \\ Email: *bekhzod_a@mail.ru
}

How to cite this paper: Bekhzod, A., Tashkhonim, R., Khabibullo, S., Nodira, R. and Yusuf, V. (2018) Succession of the Plant Communities of the Ustyurt Eastern Cliff (Republic of Uzbekistan) in Connection with Climate Change. Journal of Environmental Protection, 9, 1408-1424. https://doi.org/10.4236/jep.2018.913087

Received: September 17, 2018

Accepted: December 16, 2018

Published: December 19, 2018

Copyright $\odot 2018$ by authors and Scientific Research Publishing Inc. This work is licensed under the Creative Commons Attribution International License (CC BY 4.0).

http://creativecommons.org/licenses/by/4.0/

(c) (i) Open Access

\begin{abstract}
A decrease in the amount of precipitation is observed on average $18-20 \mathrm{~mm}$ compared with the periods before the Aral crisis and the average annual temperature rise over the long-term period is $2.0^{\circ} \mathrm{C}$ in the Central part of Ustyurt. An increase in the $S i$ index meaning an increase in the degree of drought every ten-flight is clearly expressed in the months March-July. Data Analysis 1981-2017 shows that within 36 years the species diversity in the monitoring sites of Kabanbay decreased by 2 - 3 times. In 1981 the number of species fluctuated between the values of $9-50$, and in 2017 this figure is 4 17. The results of the analysis show that the forecast indicators of the old-current state (1981) of the vegetation coverage and number of species were stable or had tendencies with a low regressive character $\left(r^{2}=0.01\right)$. However, the current-state (2017) of the vegetation coverage and the species composition of the monitoring plots showed a low progressive trend $\left(r^{2}=\right.$ $0.03)$, i.e. in the future, the formation of plant communities with low vegetation coverage and species composition has a dominant status. The results show that in $1981,65 \%-80 \%$ of the species composition of plant communities consisted of halophyte and xerophyte groups. In 2017, this figure reaches $80 \%-100 \%$, i.e. this claims to increase xerophytization and halophytization of territories. An interesting fact is established with mesophyte group. In general, theoretically, the decrease in the number of mesophyte group of plants for 1981-2017 would have a direct correlation with the vegetation coverage and their active share in it. However, for 36 years, their active share in the vegetation coverage remained unchanged-amounting to $0 \%-20 \%$. Of course, in these years, the decrease in the number of mesophyte plants led to an increase in the number of plant communities, in which the proportion of
\end{abstract}


vegetation coverage of mesophyte group is insignificant-0\%-5\%. Despite the drought, the active part of the vegetation cover of mesophytic invasive species, such as Poa bulbosa, is consistently maintained.

\section{Keywords}

Ustyurt Plateau, Eastern Cliff, Climate Change, Species Diversity, Total Projective Cover, Invasive Species

\section{Introduction}

Current trend on climate change is recognized to be one of the greatest challenges for all life on earth [1]. Intergovernmental Panel on Climate Change (IPCC) developed scenarios which project a further increase in global mean surface temperature of $2.6^{\circ} \mathrm{C}-4.8^{\circ} \mathrm{C}$ above pre-industrial levels by the year 2100 , spatial and temporal changes in precipitation patterns, and increased incidence of floods and droughts [2]. The negative impact of climate change, if combined with continuously environmentally destructive human activities, will become more intense and frequent. The debate of potential ecological impact of ongoing climate change has intensified over the last decade [3]-[9]. It has been forecasted that climate change and its impacts may become the dominant driver of changes in ecosystem services and biodiversity loss at the global level [10]. In the context of understanding the ecological responses to climate change, it may be more relevant to understand the changes in region which are spatially heterogeneous rather than the approximated global averages [10] [11]. There are five global climate domains in the world: i.e., tropical, subtropical, temperate, boreal, and polar [12] [13]. Among all of these global climate domains, the boreal arid territories have the highest rate of plant cover degradation and destruction [14] [15] [16]. Therefore, it becomes very important to study the biodiversity-climate interaction in highly modified arid territories [17].

The Ustyurt Plateau is a desert in the west of Central Asia, located between Aral and Caspian Seas. The territory of the plateau includes the borders of Uzbekistan, Turkmenistan and Kazakhstan, and the area is 20 million hectares, about 35\% (7 million hectares) of the territory is located on the territory of the Republic of Uzbekistan (Karakalpak Ustyurt) [18]. The Ustyurt Plateau is recognized as a world-wide territory-it belongs to the global ecoregion-the Central Asian desert. This ecoregion is part of 200 global networks (Global-200), which in 1998 was included in the world ranking of regions with the most outstanding biological characteristics of terrestrial, freshwater and marine ecosystems of Earth [19].

The vegetation cover of the Eastern Cliff of the Ustyurt plateau, in comparison with other regions of the plateau, is absolutely characterized by a great variety of phytocenoses, which is explained by the heterogeneity of the environment. Despite the seeming monotony of desert landscapes, their phytocenological com- 
position is quite diverse due to the influence of the steppe flora. In the northern half of the cliff are species that do not enter the southern half. In addition, the peculiarity of the hydrological and thermal conditions of the Aral Sea is caused by the peculiarities of the relief, the proximity of the Aral Sea and is the main reason for the presence here of phytocenoses from the summer-growing mesophytic formations of tugai vegetation-Crataegeta korolkovii, Rosaeta majalisi, meadow vegetation-Medicageta sativae, and steppe vegetation-Agropyreta fragile, which are vulnerable to climate change by the accompanying drought.

The Aral Sea occupies a special place in the natural and climatic conditions of Eastern Cliff and as a large pond, softens the climate of the cliff. In connection with the lowering of the level of the Aral Sea, the humidity of the air in the coastal strip decreased. As a result, the rocks of the cliff dried up and the tendency to remove silty, saline particles on the plateau increased. As a result, in the plateau adjacent to the cliff, salinity of the soil increased. As early as the 1970s, the negative impact of a decrease in sea level on vegetation was noticeable. In this case, there is a differentiation of salts and their removal-they fall asleep herbaceous plants and covered with sand. This process is clearly expressed under the Ustiurt cliff [20], Sarybaev [21], Sarybaev, Saparov [22], Shomurodov et al. [23] [24] [25], Dimeeva [26].

In 1977-1987, in Ustyurt B. Sarybaev [21] carried out route-reconnaissance studies at 12 botanical sites and 3 half-stations due to the impact of the decline in the Aral Sea level on vegetation. The decrease in the level of the Aral Sea on different plant complexes was reflected in different ways. The vegetation of the coastal strip adjoining the shallow sea areas has changed to the greatest degree. The vegetation cover of the northern part of the Eastern Cliff of Ustyurt has not experienced major changes. However, in the Ajibay bay area, the vegetation has become poorer. If mesophytic meadow elements, such as Medicago sativa, Agropyron fragile, in the Kabanbai, Kassarma, and Aktumsyk areas, formed full-fledged phytocenoses, then in the Ajibay area they were very rare and of low productivity.

The changes of the Eastern Cliff desert phytocenoses was also studied with S. Kabulov [27], using the example of key sections of the Kosbulak profile. At the same time, the vitality of the cenopopulation of Artemisia terrae-albae is lowered in the hypsophylic phytocenoses of the elevated cliffy territories. The increase of salinity soil within the cliff depressions, role of halophilic cenopopulations (Suaeda microphylla, Climacoptera aralensis), decrease in vitality of the processes of natural renewal Artemisia terrae-albae, Salsola orientalis, gradual replacement of meadow phytocenoses (Medicago sativa) with steppe (Erogrostis collina, Agropyron fragile) were noted. It can be assumed that meadow, steppe phytocenoses, as well as fragments of tugai vegetation of the Ustyurt cliff in the conditions of further desiccation of the Aral Sea completely degrade.

According to B. Sarybayev [21] [22], in 1965-1970 in the Eastern Cliff-Kabanbai region, of the desiccated part of the sea, the processes of desertification have not 
yet been widely developed due to the small dimensions of the dried bottom of the sea. The species of the Suaeda acuminata and Atriplex tatarica species acted as pioneer species liberating from the water. However, the part of the sea, dried in 1978, due to the sharp descent of the topwater, remained a bare territory with spotted salinity. On the drained land in 1976, the Suaeda acuminata and the Atriplex tatarica were replaced by Stipagros tiskarelinii. Thus, here only within a year the Suaeda acuminate + Atriplex tatarica phytocenosis disappeared. A characteristic feature of the drained part of the sea of this region is the absence of dunes with the Lycium ruthenicum and intensive formation of hills and sand dunes with Arestida Karelini. In 1986-1987, the Arestida Karelini began to gradually become oppressed, diluted and replaced by Calligonum aralense with the participation of an Eremosparton aphyllum. Thickets of Haloxylon aphyllum began to be oppressed.

However, historical space images in the period 1976-2016 show that in the Kabanbai territory there is a constant retreat of the water of the Aral Sea from the cliffy coast (Figure 1). Especially in the 1990s, there was a sharp reduction in the coastline of water to $5 \mathrm{~km}$, resulting in the formation of 4200.0 hectares saline sand massif. At present (2016) the coastline has retreated to $25-30 \mathrm{~km}$ and the large solonchak massifs that formed here could not reflect on the state of the vegetation of the adjacent territories.

These data mean that the Aral Sea from the initial desiccation (1960-1970) contributed negatively to vegetation, developing the formation of succession processes. Taking into account the increasing shrinking of the Aral Sea, and in connection with this progress in the climate change of the territory in the future, we estimated the current state of the Eastern Cliff vegetation in a comparative aspect based on the Kabanbai profile made by Sarybaev in 1981 [20].

\section{Materials and Methods}

The Ustyurt Plateau is an elevated area in the central part of the Turan Lowland. It is bordered by cliffs on almost all sides. The cliff from the east is formed by the former western shore of the Aral Sea (Figure 2).

The plateau falls to the Kunya Dar'insk ancient alluvial plain and the Uzboi River Valley in the south, to the Karynyaryk Depression and the Northern Caspian Karakumy Sands in the west, and to the Caspian Sea Lowland in the North [25].

The Eastern cliff is a huge, morphologically rugged, arid stony desert. The Eastern Cliff delimits the eastern part of the plateau with a broken line and it is the natural geographical boundary of the Ustyurt plateau. The Eastern Chick of Ustyurt is feed by atmospheric precipitation. There are no permanent rivers, but there are seasonal surface runoffs that feed on atmospheric precipitation. The climatic conditions of the Eastern Cliff are characterized by a sharp continentality. The Aral Sea, washing the Eastern Cliff, affects its climate. Fogs are quite frequent, the air is more humid, the precipitation is somewhat greater than on 


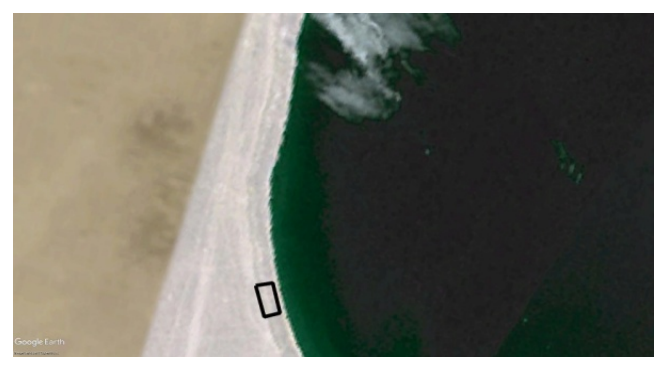

1974

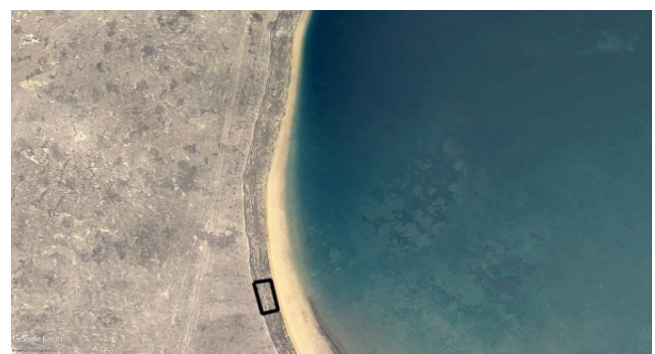

1988

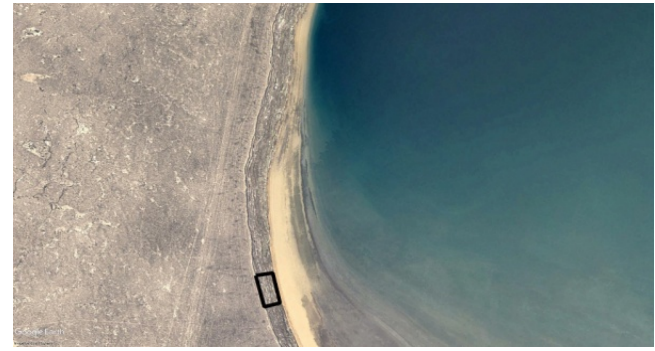

1996

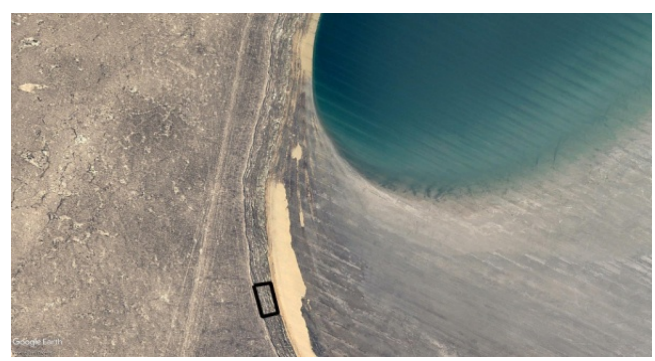

2004

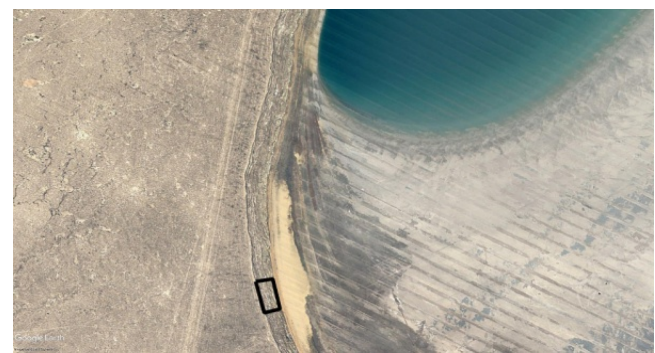

2012

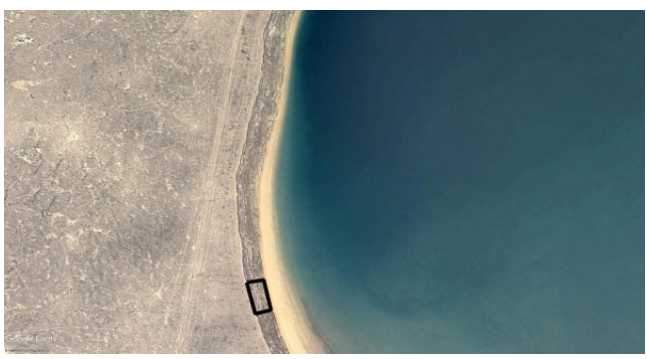

1984

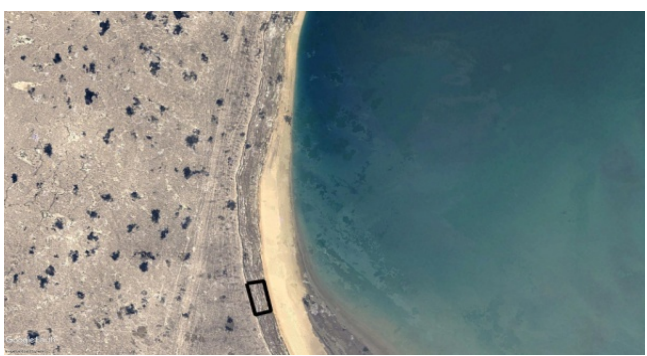

1992

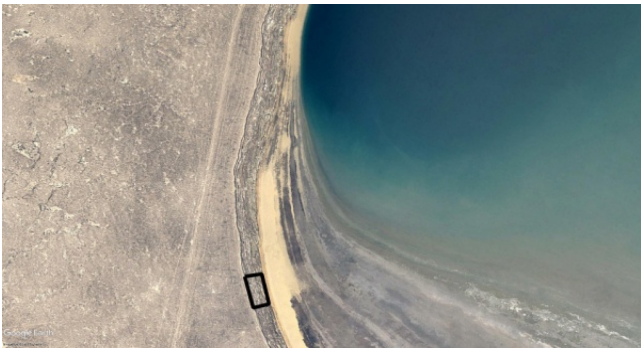

2000

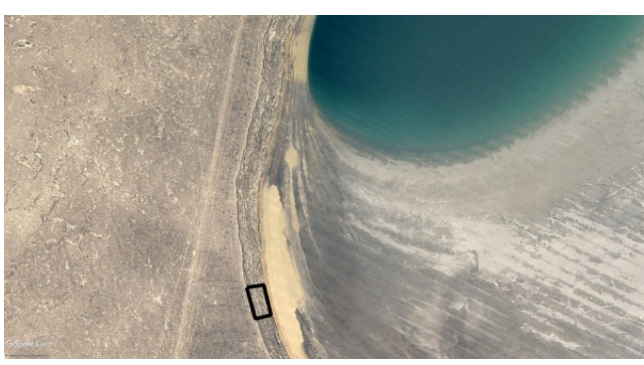

2008

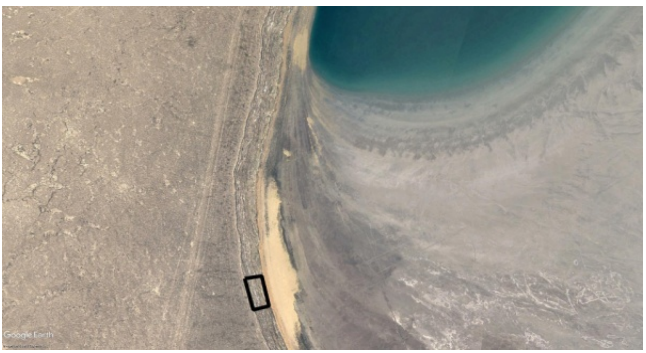

2016

Figure 1. Reductions in the level of the Aral Sea in the Kabanbai hole in the period 1973-2016 (the territory of the Eastern cliff, Ustyurt Plateau). The marked square is the key botanical territory which began monitoring from 1981 (Sarybaev, 1981). 

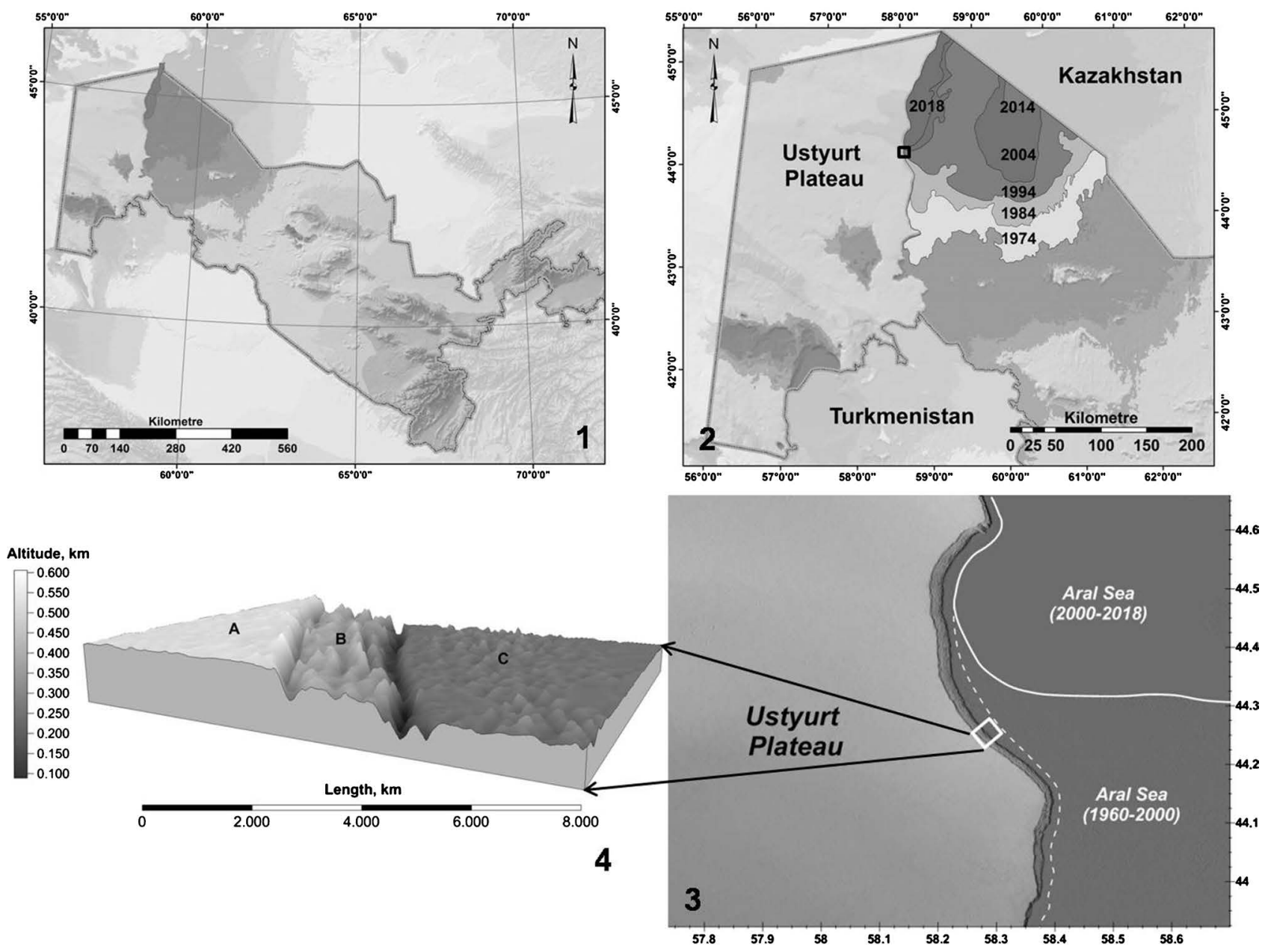

Figure 2. Locations of Karakalpak part of Ustyurt plateau ((1), (2)). Years means a corresponding decrease in the level of the Aral sea. With a square shows the monitoring plot Kabanbay; the location of the Eastern cliff of the Ustyurt plateau (3); General view of the monitoring plot Kabanbay (4). In the Western side of Kabanbay (B) there is the territory of Ustyurt plateau (A), and in the North-the exposed Aral seabed (C).

sections of the plateau remote from the sea [20].

The Kabanbai profile is located $1-1.5 \mathrm{~km}$ north of the Kabanbai descent of the Eastern Cliff. The length of the profile is $3250 \mathrm{~m}$. The height of the cliff is $230 \mathrm{~m}$ (Figure 2).

The leveled topography and the lack of water courses and publicly available fresh water make the plateau one of the most arid and extreme areas of the region. According to the botanical geographical zoning of Kazakhstan and Middle Asia (in the desert region), the Ustyurt Plateau was assigned to the western-northern Turan subprovince of the northern Turan province by E.I. Rachkovskaya [28] and others. The total solar radiation in the northern Turan desert is $130-140 \mathrm{kcal} / \mathrm{cm}^{2}$ per year, and the radiation balance is $45-50 \mathrm{kcal} / \mathrm{cm}^{2}$ per year. The total of temperatures above $10^{\circ} \mathrm{C}$ is $3600^{\circ} \mathrm{C}$. The mean temperature is $10^{\circ} \mathrm{C}$ for January and $26^{\circ} \mathrm{C}-29^{\circ} \mathrm{C}$ for July. The growing period lasts $200-210$ days (240 - 270 days in the southern Turan desert). The precipitation regime is similar to the Mediterranean type. The total precipitation is $100-150 \mathrm{~mm}$ per 
year. The snow cover in the northern part of the plateau is more stable [28]. The water and temperature regimes are characterized by the dryness index (2.5 - 6.0).

Geobotanical descriptions were performed in all communities where the population structure of the species was studied, according to the generally accepted method at sites of $100 \mathrm{~m}^{2}$ [29] [30].

The degree of participation is denoted by figures on the 7-point system of $\mathrm{R}$. Drude [31]: solo-sol, rare- $\mathrm{sp}^{1}$, quite rare- $\mathrm{sp}^{2}$, mediocre- $\mathrm{sp}^{3}$, close-cop ${ }^{1}$, quite close-cop ${ }^{2}$, abundant-cop ${ }^{3}$.

Plant names are given in the latest bulletin S.K. Czerepanov [32] and on the site www.the plantlist.org.

For a general comparative assessment of the climate change in the Ustyurt Plateau, we established linear trends and their significance in the long-term dynamics of precipitation for different time periods on the basis of the long-term meteorological data of the "Zhaslyk" (Central Ustyurt) meteorological station in 1976-2015. Along with the analysis of long-term trends, a comparative analysis of the temperature regime and the nature of precipitation during the years 1980-2015 was carried out in comparison with the historical period (1960-1980) to the development of the Aral Sea crisis at the "Zhaslyk" meteorological station. The total amount of atmospheric precipitation and the average air temperature were analyzed.

Features of the manifestation of atmospheric droughts are determined by the aridity index Ped [33].

The statistical characteristics were obtained using the "Statistica-10" packages.

\section{Results and Discussion}

\subsection{Changes Main Climate-Forming Factors of the Ustyurt Plateau}

Climate prediction is one of the important tasks in developing climate change scenarios and developing appropriate adaptation measures based on their analysis. From this position, a statistical description of the future state of the climate system and the variability of the characteristics of its components at different time periods appears to be the main step in the system of measures to reduce the vulnerability of biodiversity elements from climate change [34].

Analyzes of the meteorological data of the Eastern Cliff area show that in recent years there have been certain trends in the distribution of atmospheric precipitation and the average monthly air temperature.

In the long-term distribution of annual precipitation sums, a negative trend was identified $(r=0.02)$ (Figure 3$)$. The main reasons for the decrease in the trend indicator are associated with 4 observation points, indicating a very dry period $(1983,1996,2000,2007)$ with an annual total precipitation of only 40 to $60 \mathrm{~mm}$. In the territories of the Eastern Cliff, a decrease in the amount of atmospheric precipitation on average $18-20 \mathrm{~mm}$ is observed compared with the periods before the active anthropogenic impact. The amplitude of precipitation changes $\left(K_{\text {chang }}\right)$ is more than $13 \%$. 
For average air temperatures (medium long-term) only positive trends were detected $\left(r_{\min }=0.1, r_{\max }=0.2\right)$. At the same time, the interval of long-term average temperature shows $9.8^{\circ} \mathrm{C}-11.3^{\circ} \mathrm{C}$. An increase in the average annual temperature over a long period is on average $2.0^{\circ} \mathrm{C}$. The prevailing and the only trend in the long-term distribution of the average annual air temperature is a stable increase, which is reliably due to warming of the air, both in the cold and in the warm half-year. At the same time, in the cold periods of the year the temperatures rise with a slightly larger amplitude (especially $1-2$ months), rather than in warm ones. The amplitude of changes $\left(K_{\text {chang }}\right)$ of the average air temperature is $49 \%$ - $55 \%$.

Analysis of values of calculated aridity index Ped made it possible to reveal some general patterns for the Ustyurt plateau and neighboring territories (Table 1). Aridity index Ped $\left(S_{i}\right)$ calculated with respect to the base period showed that the climate of all the stations under analysis undergoes changes in comparison with the periods of 1960-2015, which is related to warming and drying, which

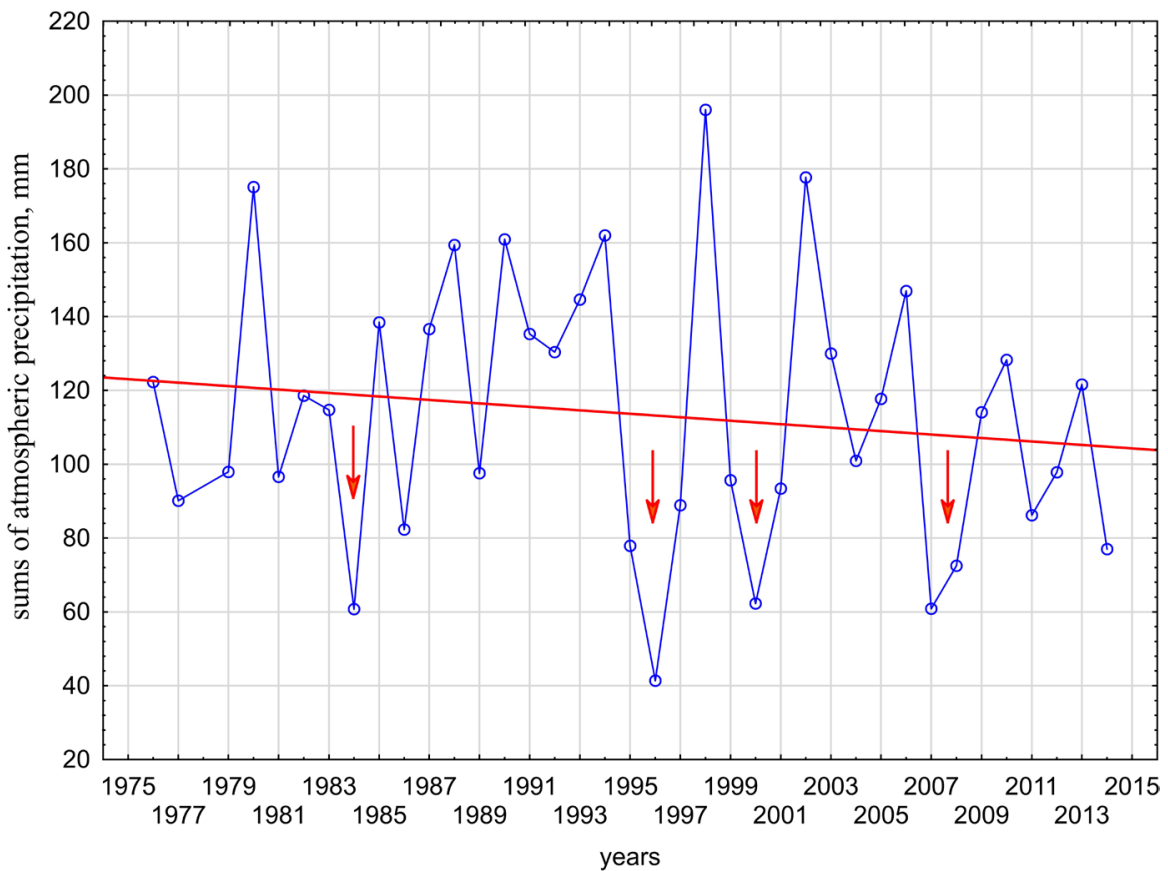

Figure 3. The multi-annual tendency of sums of atmospheric precipitation for the meteorological station "Zhaslyk".

Table 1. Index Pedya (Si) for the meteorological station "Zhaslyk".

\begin{tabular}{cccccc}
\hline \multirow{2}{*}{ Years } & \multicolumn{5}{c}{ Months } \\
\cline { 2 - 6 } & March & April & May & June & July \\
\hline $1976-1985$ & 0.6 & 2.6 & 4.0 & 1.9 & 2.7 \\
$1986-1995$ & 0.9 & 1.5 & 1.9 & 3.6 & 1.8 \\
$1996-2005$ & 1.5 & 2.7 & 2 & 2.4 & 2.7 \\
$2006-2015$ & 1.7 & 2.0 & 4.9 & 5.2 & 3.4 \\
\hline
\end{tabular}


mainly occurs in the active vegetation period-in the spring-summer season of the year. The increase in the indicator Si, which signifies the intensification of the degree of drought, every ten-year is clearly expressed in the months March-July. Especially, in March, every ten years of the transition of the Si index from the "normal moistening condition" (0.6) to the "weak drought" (1.7) confirms further intensification of aridization in the early spring period in the territory of Eastern Cliff.

\subsection{Changes of Vegetation Indicators of the Eastern Cliff}

According to B. Sarybayev [20], in 1981 for the profile of Kabanbai, the following sequence of associations was inherent in proportion to the approach to the Aral sea (total of 17 plant communities): Salsoleta arbusculae + Artemisieta terra-albae $\rightarrow$ Sisselieta glabratum $\rightarrow$ Rosaeta majalisi $\rightarrow$ Mixgrasseta + Rosaeta majalisi + Crataegeta korolkovii $\rightarrow$ Mixgrasseta + Artemisieta terra-albae $\rightarrow$ Ephemereta + Haloxyleta aphyllai $\rightarrow$ Artemisieta terra-albae + Salsoleta arbusculae $\rightarrow$ Artemisieta terra-albae + Salsoleta orientale $\rightarrow$ Ephedreta distachya $\rightarrow$ Ephemereta + Artemisieta terra-albae $\rightarrow$ Salsoleta arbusculae $\rightarrow$ Halocnemeta strobilacei $\rightarrow$ Anabaseta salsae $\rightarrow$ Phragmiteta australis + Tamariceta androssovii $\rightarrow$ Salsoleta arbusculae + Artemisieta terra-albae $\rightarrow$ Eremopyreta orientale + Haloxyleta aphyllai.

We have studied this profile in 2016-2017 and identified some changes in syntaxa compared with the data of B. Sarybaev [20]. According to our data-after 36 years, the sequence of associations as they approach the sea looks as follows (total 27 plant communities): Mixgrasseta + Artemisieta diffusae + Mixshrub $\rightarrow$ Echinopeta Meyeri $\rightarrow$ Mixgrasseta + Rosaeta majalisi $\rightarrow$ Atraphaxeta spinosae $\rightarrow$ Mixgrasseta + Atraphaxeta spinosae $\rightarrow$ Atraphaxeta spinosae + Salsoleta arbusculae $\rightarrow$ Mixgrasseta + Rosaeta majalisi + Atraphaxeta spinosae $\rightarrow$ Artemisieta diffusae + Salsoleta orientale $\rightarrow$ Atraphaxeta spinosae + Artemisieta diffusae $\rightarrow$ Artemisieta diffusae $\rightarrow$ Haloxyleta aphyllai $\rightarrow$ Salsoleta orientale + Poa bulbosae $\rightarrow$ Artemisieta diffusae $\rightarrow$ Artemisieta diffusae + Haloxyleta aphyllai $\rightarrow$ Poa bulbosae + Artemisieta diffusae $\rightarrow$ Mixgrasseta + Artemisieta diffusae $\rightarrow$ Artemisieta diffusae + Anabaseta salsae $\rightarrow$ Annual halophyeta + Anabaseta salsae + Artemisieta terra-albae $\rightarrow$ Salsoleta arbusculae + Artemisieta diffusae $\rightarrow$ Artemisieta diffusae $\rightarrow$ Annual halophyeta + Anabaseta salsae $\rightarrow$ Artemisieta terra-albae $\rightarrow$ Artemisieta diffusae + Salsoleta arbusculae $\rightarrow$ Anabaseta salsae + Salsoleta arbusculae + Artemisieta diffusae $\rightarrow$ Salsoleta orientale + Artemisieta terra-albae $\rightarrow$ Artemisieta terra-albae $\rightarrow$ Nitrarieta schoberi + Haloxyleta aphyllai.

When comparing the vegetation cover peculiarities of the Kabanbai profile in 1981 and 2017, the following results were obtained.

\subsubsection{Species Diversity and Total Projective Cover (TPC)}

Analysis of the data 1981-2017 shows that within 36 years the species diversity along the Kabanbai profile has decreased by 2 - 3 times. If in 1981 the number of species fluctuated between 9 - $50(9<>50)$, and in 2017 this figure is $4<$ and $>17$ 


\section{(Table 2).}

In this case, it should be noted the change in the weight index $(\Delta)$ of the species composition (SC), which means the largest accumulated number of species quantity. In the 1980s, although the magnitude of the species abundance is larger $(9<>50)$, the $\Delta S C$ index is located between $40-50$, which means a large spread of those plant communities that consist of 40 - 50 species. In 2017, the indicator $\triangle S C 2$ - 3 times less $(\triangle S C=15-17)$ than 1981, which confirms a sharp reduction in active plant communities with a high floral composition (Figure 4).

According to B. Sarybaev [20], in this territory communities with a total projective cover (TPC) of at least $40 \%$ were widely distributed. In some communities the species composition is insignificant, but TPC reaches up to $90 \%$. For example, the TPC of the Rosaeta majalisi community, consisting of only 8

Table 2. Indicators of vegetation Kabanbai monitoring site.

\begin{tabular}{|c|c|c|c|}
\hline \multirow[b]{2}{*}{ № } & \multirow[b]{2}{*}{ Indicators } & \multicolumn{2}{|c|}{ Observation years } \\
\hline & & 1981 & 2017 \\
\hline & Total projective coverage, $\%$ & $<40$ & $>40$ \\
\hline 1. & $\Delta$ total projective coverage, $\%$ & $60-80$ & $20-50$ \\
\hline & Species diversity & $9<>50$ & $4<>17$ \\
\hline 2. & $\Delta$ species diversity & $40-50$ & $15-17$ \\
\hline 3. & Proportion of xerophyte/halophytes in the species composition, $\%$ & $65-80$ & $80-100$ \\
\hline 4. & $\begin{array}{l}\text { Proportion of mesophyte/xeromezophytes } \\
\text { in the species composition, } \%\end{array}$ & $25-35$ & $0-20$ \\
\hline & $\begin{array}{l}\text { Proportion of projective coverage (\%) } \\
\text { of xerophyte/halophyte plant groups }\end{array}$ & $80-100$ & $80-100$ \\
\hline 5. & Mediana & 88 & 95 \\
\hline & Proportion of projective coverage (\%) of mesophyte plant group & $0-20$ & $0-20$ \\
\hline 6. & Mediana & 15 & 10 \\
\hline
\end{tabular}
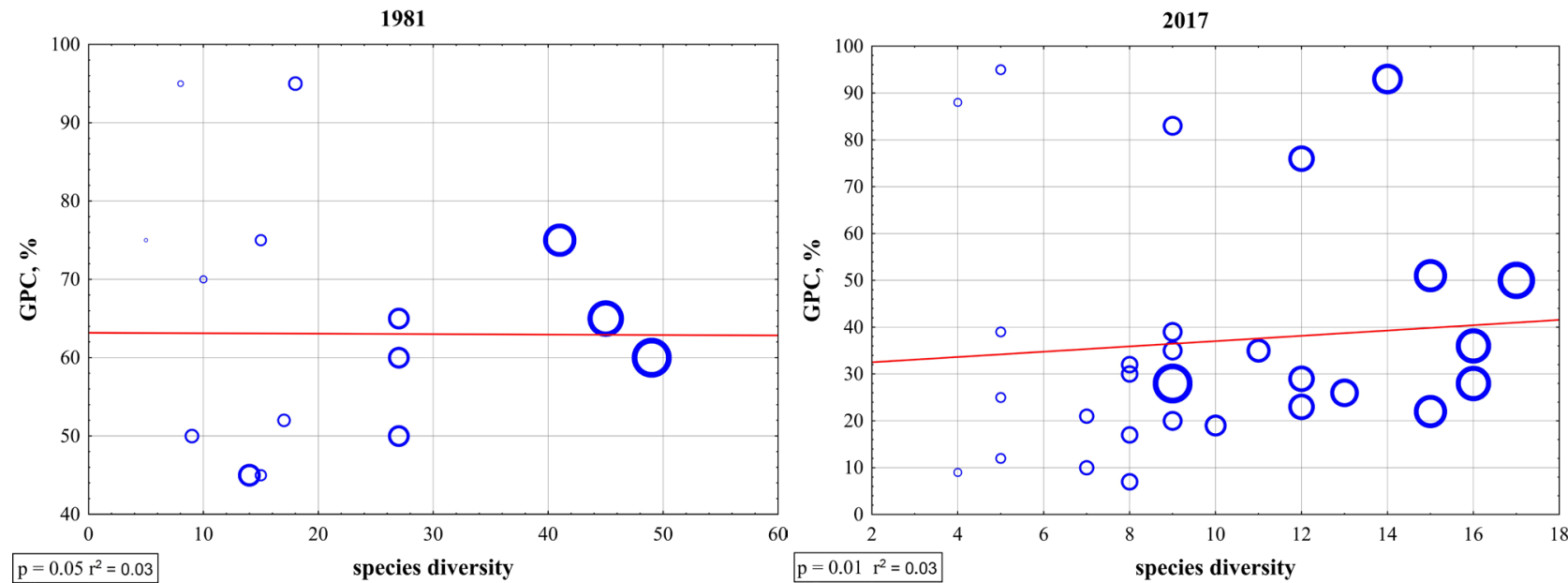

Figure 4. Dispersion diagram of TPC (\%) and species diversity of vegetation. 
mesophyte and xerophyte species, was $95 \%$. A similar picture was also observed in the Crataegeta korolkovii, Sisselieta glabratum + Salsoleta arbusculae, Halocnemeta strobilacei communities that are formed on the basis of xerophilic and halophilic plant groups. In general, in 1981, the $\triangle T P C$ indicator as of the state in the dispersion diagram is accumulated between 60 and 80 .

As the results showed, that after 36 years (2017), the $\triangle T P C$ profile value corresponds to between 20 - 50, and this means a reduction of TPC in recent years to $30 \%$ - 40\%. However, TPC in some communities, consisting of xerophyte/halophyte groups, were preserved with high values. For example, the TPC of the Artemisieta diffusae + Haloxyleta aphyllai community with 4 species reaches $88 \%$, and in the Artemisieta diffusae community with 5 species-95\%. TPC of plant communities, consisting of mesophyte plants group, does not exceed 30\% (Table 2; Figure 4).

The trends of the old-current (1981) and modern-current states (2017) of the $T P C$ and the species diversity of the Kabanbai profile in the dispersion diagram are analyzed. The analysis results show that the predicted parameters of the old-current state of TPC and species composition were stable or had trends with a low regressive character $\left(r^{2}=0.01\right)$. However, the modern-current state of the $T P C$ and the species composition of the Kabanbai profile showed a low progressive trend $\left(r^{2}=0.03\right)$, that is, in the future the formation of plant communities with low projective cover and species composition has a dominant status.

Changes in species diversity and $T P C$ as a result of various factors, including droughts, do not fully demonstrate the aridization of the territories. A decrease in the proportion of mesophytes in the species composition and/or the projective cover of mesophytes in $T P C$, or vice versa an increase in the proportion of xerophilic and halophilic groups in the species composition and/or their projective cover in the plant cover, can give a true picture of changes in the vegetation cover due to climate change.

\subsubsection{Proportion of Xerophyte/Halophyte and Mesophytes in Species Composition}

Climate change accompanying with drought, in the first stage, creates favorable conditions for the appearance of adaptive species in the territories. Further drying of soil and air temperature leads to the destruction of unstable mesophyte species, more distribution of xerophytic and halophytic plant species [35] [36] [37].

The results show that in $1981,65 \%-80 \%$ of the species composition of plant communities was made up of halophyte and xerophyte groups (Table 2; Figure 5). 2017 this indicator reaches $80 \%-100 \%$, i.e. this confirms the strengthening of xerophytization and halophytization of territories. In addition, a change in the composition of dominant xerophyte/halophyte species by 2017 has been established. Unlike in 1981 (Tamarix androssovii, Halocnemum strobilaceum, Anabasis salsa, Haloxylon aphyllum, Salsola orientalis, Salsola arbuscula, Artemisia terra-alba), in recent years the species composition of the communities has been 


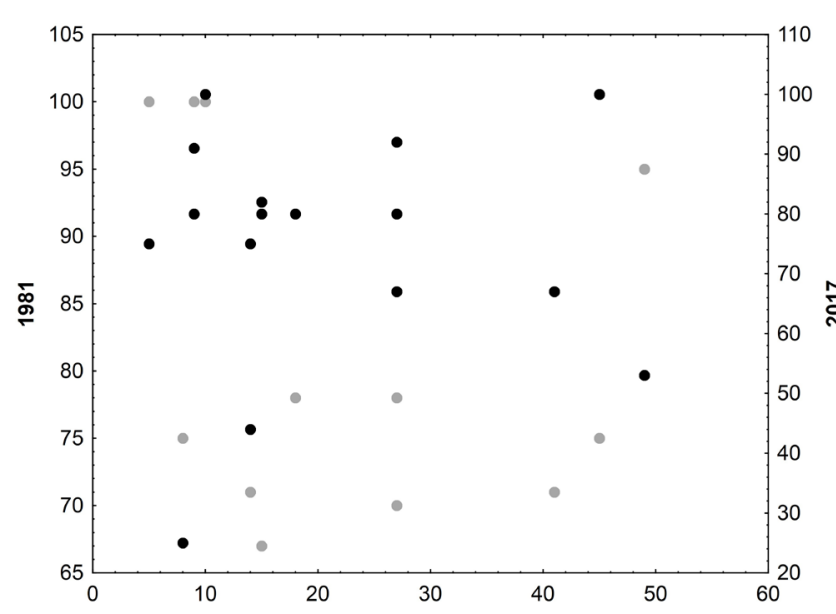

(a)

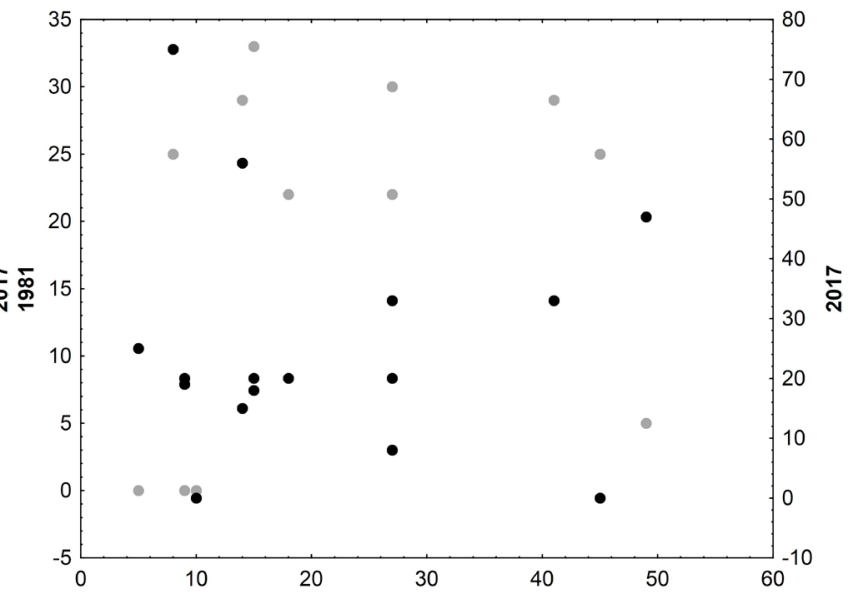

(b)

Figure 5. Proportion of xerophyte/halophytes, \% (a) and mesophytes, \% (b) on species composition in 1981 (gray) and 2017 (black).

"enriched" with such xerophyte/halophyte species as Artemisia diffusa, Artemisia turanica, Atraphaxis spinosa, Salsola arbusculiformis.

Particularly, a decrease in the number of Artemisia terra-alba as a significantly mesophilic origin and an increase in the proportion of sagebrush with a more xerophilic character-Artemisia diffusa was revealed. In the profile of Kabanbai B. Sarybaev [20] indicated sagebrush communities only with the participation of Artemisia terra-alba. The results show that of the 11 revealed sagebrush communities in 7 (64\%), Artemisia diffusa dominates. In addition, the number of Atraphaxeta spinosae community has markedly increased, characteristic of savannas foothills and remote mountains, as well as ecosystems of southern warm-temperate deserts (ecosystems of island lowlands). At the same time, Atraphaxeta spinosae, Mixgrasseta + Atraphaxeta spinosae, Mixgrasseta + Rosaeta majalisi + Atraphaxeta spinosae, Atraphaxeta spinosae + Anabaseta salsae and Atraphaxeta spinosae + Artemisieta diffusae communites were registered, which were not noted by B. Sarybayev [20] in the profile of Kabanbai.

B. Sarybaev [20] gave dates on the presence of Rosaeta majalisi and Crataegeta korolkovii associations in the territory of Kabanbai. In this area there was no marked superiority of mesophyte plants, and the species composition of $25 \%$ $35 \%$ consisted of mesophytes (Table 2; Figure 5 ). As the most widespread species, the following can be cited: Geranium transversale, Taraxanum bicorne, $\mathrm{Tu}$ lipa biflora, Thalictrum isopyroides, Tragapogon marginifolius, Rosa majalis, Agropyron repens, Agropyron fragile, Crataegus korolkovii, Corydalis schanginii, Galium pamiralaicum, Cressa cretica, Allium sabulosum, Gagea afganica, Medicago sativa, Malcolmia africana, Cynoglossum viridiflorum, Convolvulus arvensis, Cynanchum sibiricum.

Current research shows (2017) a decrease in the proportion of mesophyte plants in the species composition of communities to $0 \%-20 \%$. Especially, it is important note, that the absence of such more mesophyte plants, as Geranium 
transversale and Corydalis schanginii, as well as a decrease in the degree of presence in Agropyron repens, Agropyron fragile and Medicago sativa communities.

\subsubsection{Proportion of Projective Cover (\%) of Xerophyte/Halophyte and Mesophyte Plant Groups}

It is important note that, a decrease in TPC for 36 years due to increased drought did not affect the reduction in the proportion (\%) of the projective cover of xerophyte/halophyte plants groups. Since in the both studied years (1981, 2017), the intermediate distance of the proportion of projective cover of such plant groups is $80 \%-100 \%$ (Figure 6). However, in contrast to 1981, in 2017 the number of communities increased which TPC completely (100\%) formed due to the projective cover of xerophyte/halophytes. This is explained by the fact, that in recent years the number of communities with the participation of Atraphaxis spinosa and Artemisia diffusa has significantly increased in the vegetation cover of the Eastern cliff, whose shares in 1981 were insignificant. This is also confirmed by increase number of Mediane from 88 (1981) to 95 (2017).

The most interesting fact is also established with mesophyte group. Theoretically, a decrease in the number of mesophyte plants in 1986-2017 would have a direct correlation with the TPC of the herbage and with their active share in it. However, for 36 years, their active share in the TPC remained unchanged-making up $0 \%$ $20 \%$ (Figure 6). Unconditionally, in these years, the decrease in the number of mesophyte plants, led to an increase in the number of plant communities in which the proportion of the projective cover of mesophytes is negligible- $0 \%$ $5 \%$.

Despite the drought, stable maintenance of the active share of the projective cover of mesophyte plant group in TPC for 36 years is explained by the intensification of the dominant nature of some mesophyte plants. In particular, it is

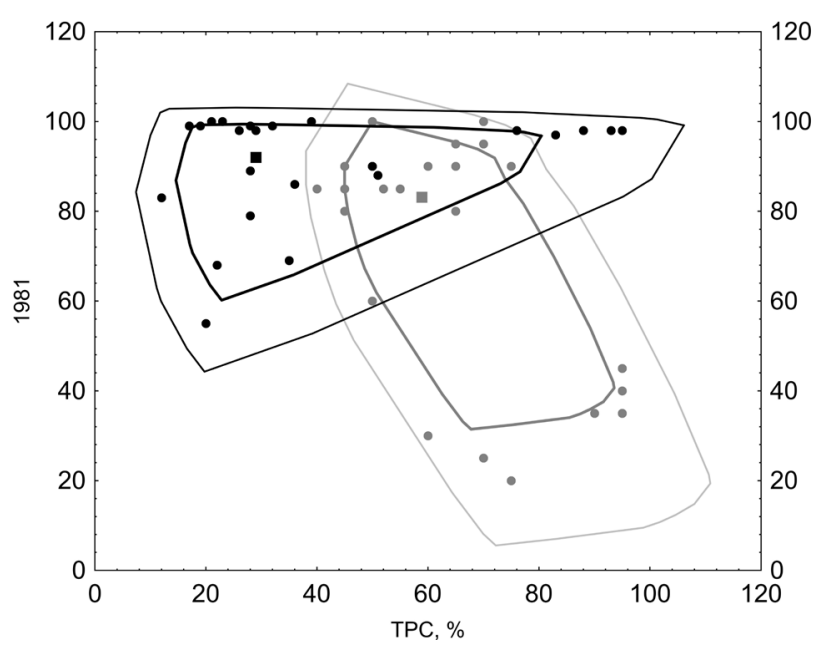

(a)

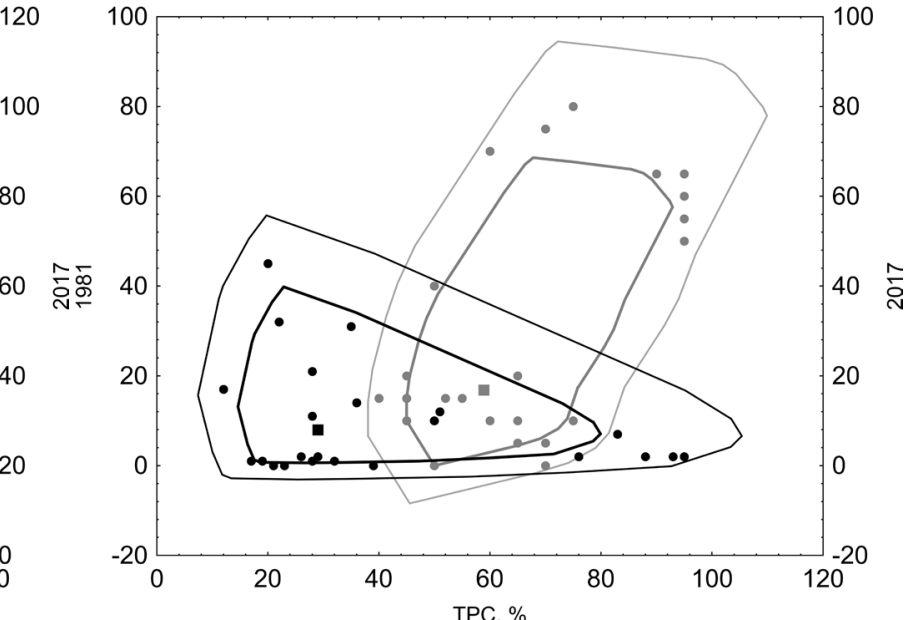

(b)

Figure 6. Proportion of projective coverage (\%) of xerophyte/halophyte (a) and mesophyte (b) plant groups in the total projective coverage of vegetation (\%) in 1981 (gray) and 2017 (black). 
important to note the increase in the share of the projective cover of the ephemeroid Poa bulbosa in recent years. If Poa bulbosa in all profile communities participated in a single quantity in 1980, in recent years, its predominance in vegetation cover has been observed.

At the same time, it is important to note the research results of L.A. Dimeeva [26], about the natural and anthropogenic dynamics of vegetation of the Aral and Caspian deserts region. The author emphasizes that under the influence of various factors, in the plant cover there is a decrease or destruction of unstable species and in future their place is occupied by native species with ruderal strategy, like Poa bulbosa and others.

In addition, N.K. Boote [38] and Birsen Karakug [39] approved that, Poa bulbosa is an invasive species to shows intensive diffusion, occupying the deserted territories in the states of Washington, Idaho and Montana, and the territories of Turkey.

Invasive species present one of the greatest threats to the health and sustainability of ecosystems worldwide. Climate change is expected to alter the distribution and spread of invasive plants but in largely unknown ways. Climate change may favor and convert non-native species considered benign today into the noxious weeds of tomorrow, but we are unable to predict which species might be favored [40] [41] [42].

According to our opinions, not only non-native species, but also native species, can be manifested or applied an invasive strategy, when favorable conditions are creation for their distribution in connection with climate change. We believe that the prevalent level of mesophyte species in TPC after 36 years in Kabanbai, despite a sharp decline mesophyte species in plant communities, is associated with the disappearance of the most vulnerable to drought species and seizure of empty areas by plants from ruderal or invasive strategies for self-maintenance of populations.

\section{Conclusions}

Plant cover and community composition are vital signs that are monitored across climate changes. The abundance, distribution, and interaction of many plant species and functional types are likely to respond differently to future changes in precipitation and temperature, creating novel communities. Shifts in plant community composition can have far-reaching effects on ecosystem properties, including plant diversity. Integration of climate and plant community composition vital sign data is essential to provide resource managers with tools to forecast climate change and its effect on ecosystems.

The degree of changes in the vegetation cover of the Eastern Cliff, as a result of climate change, arises in connection with the formation of ecological adaptation plant groups. At the same time, the number of key mesophyte communities of the Eastern Cliff and the diversity of their compilers is reduced, which was the main biological diversity of the Ustyurt Plateau. 
An increase in drought in the Eastern Cliff of the Ustyurt Plateau created an environment for the active formation of plant communities with the participation of xerophyte and halophyte plant group. This is due to the fact that the degree of projective cover and biological diversity of communities based on these plant groups has remained unchanged, despite the gradual increase in drought for 36 years. In the Eastern Cliff, in the future, the formation of plant communities with low projective cover and biological diversity has a dominant status.

\section{Acknowledgements}

Funding for this project was provided by the Academy of Sciences of the Republic of Uzbekistan and the Ministry of Innovation Republic of Uzbekistan.

\section{Conflicts of Interest}

The authors declare no conflicts of interest regarding the publication of this paper.

\section{References}

[1] Fitzpatrick, M.C., Gove, A.D., Sanders, N.J. and Dunn R.R. (2008) Climate Change, Plant Migration, and Range Collapse in a Global Biodiversity Hotspot: The Banksia (Proteaceae) of Western Australia. Global Change Biology, 14, 1337-1352. https://doi.org/10.1111/j.1365-2486.2008.01559.x

[2] IPCC (2014) Climate Change 2014: The Physical Science Basis. In: Solomon, S., Qin, D., Manning, M., Chen, Z., Marquis, M., Averyt, K.B., Tignor, M. and Miller, H.L., Eds., Contribution of Working Group I to the Fifth Assessment Report of the Intergovernmental Panel on Climate Change, Cambridge University Press, Cambridge, United Kingdom, 560.

[3] Alice, C.H., Satasook, S., Bates, P.J., Bumrungsri, S. and Jones, G. (2012) The Projected Effects of Climatic and Vegetation Changes on the Distribution and Diversity of Southeast Asian Bats. Global Change Biology, 18, 1854-1865. https://doi.org/10.1111/j.1365-2486.2012.02641.x

[4] Beaumont, L.J., Pitman, A., Perkins, S., Zimmermann, N.E., Yoccoz, N.G. and Thuiller, W. (2011) Impacts of Climate Change on the World's Most Exceptional Ecoregions. Proceedings of the National Academy of Sciences of the United States of America, 108, 2306-2311. https://doi.org/10.1073/pnas.1007217108

[5] Belgacem, O.A., Salem, B.H., Bouaicha, A. and El-Mourid, M. (2008) Communal Rangeland Rest in Arid Area, a Tool for Facing Animal Feed Costs and Drought Mitigation: The Case of Chenini Community, Southern Tunisia. Journal of Biological Sciences, 8, 822-825. https://doi.org/10.3923/jbs.2008.822.825

[6] Dawson, T.P., Jackson, S.T., House, J.I., Prentice, I.C. and Mace, G.M. (2011) Beyond Predictions: Biodiversity Conservation in a Changing Climate. Science, 332, 53-58. https://doi.org/10.1126/science. 1200303

[7] Gilman, S.E., Urban, M.C., Tewksbury, J., Gilchrist, G.W. and Holt, R.D. (2010) A Framework for Community Interactions under Climate Change. Trends in Ecology \& Evolution, 25, 325-331. https://doi.org/10.1016/j.tree.2010.03.002

[8] Pereira, H.M., Leadley, P.W., Proença, V. and Alkemade, R. (2010) Scenarios for Global Biodiversity in the 21st Century. Science, 330, 1496-1501. https://doi.org/10.1126/science.1196624 
[9] Salamin, N., Wüest, R.O., Lavergne, S., Thuiller, W. and Pearman, P.B. (2010) Assessing Rapid Evolution in a Changing Environment. Trends in Ecology \& Evolution, 25, 692-698. https://doi.org/10.1016/j.tree.2010.09.009

[10] Bonebrake, T.C. and Mastrandrea, M.D. (2010) Tolerance Adaptation and Precipitation Changes Complicate Latitudinal Patterns of Climate Change Impacts. Proceedings of the National Academy of Sciences of the United States of America, 107, 12581-12586. https://doi.org/10.1073/pnas.0911841107

[11] Walther, G.R., Post, E., Convey, P., Menzel, A., Parmesan, C., Beebee, T.J. and Bairlein, F. (2002) Ecological Responses to Recent Climate Change. Nature, 416, 389-395. https://doi.org/10.1038/416389a

[12] FAO (2000) Global Ecological Zoning for the Global Forest Resources Assessment. FRA Working Paper 56. FAO, Rome.

[13] FAO (2012) Global Ecological Zones for FAO Forest Reporting: 2010 Update. FRA Working Paper 179. FAO, Rome.

[14] Deb, J.C., Phinn, S., Butt, N. and McAlpine, C.A. (2017) The Impact of Climate Change on the Distribution of Two Threatened Dipterocarp Trees. Ecology and Evolution, 7, 2238-2248. https://doi.org/10.1002/ece3.2846

[15] Hansen, M.C., Potapov, P.V., Moore, R., Hancher, M., Turubanova, S., Tyukavina, A. and Loveland, T. (2013) High-Resolution Global Maps of 21st-Century Forest Cover Change. Science, 342, 850-853. https://doi.org/10.1126/science.1244693

[16] Morris, R.J. (2010) Anthropogenic Impacts on Tropical Forest Biodiversity: A Network Structure and Ecosystem Functioning Perspective. Philosophical Transactions of the Royal Society B: Biological Sciences, 365, 3709-3718. https://doi.org/10.1098/rstb.2010.0273

[17] Wilson, M.C., Chen, X., Corlett, R.T., Didham, R.K., Ding, P., Holt, R.D. and Jiang, L. (2016) Habitat Fragmentation and Biodiversity Conservation: Key Findings and Future Challenges. Landscape Ecology, 31, 219-227. https://doi.org/10.1007/s10980-015-0312-3

[18] Bykova, E.A. (2017) Conservation of the Biodiversity of the Ustyurt Plateau, Environmental Legislation and Combating the Illegal Use of Wildlife. Fan, Tashkent.

[19] Olson, D.M. and Dinerstein, E. (1998) The Global 200: A Representation Approach to Conserving the Earth's Most Biologically Valuable Ecoregions. Conservation Biology, 12, 502-515. https://doi.org/10.1046/j.1523-1739.1998.012003502.x

[20] Sarybaev, B.P. (1981) Flora and Vegetation of the Eastern Cliff. Fan, Tashkent.

[21] Sarybaev, B.P. (1994) Flora and Vegetation of the Ustyurt Plateau and Prospects for Their Use. Dissertation, Institute of Botany, Tashkent.

[22] Sarybaev, B.P. and Saparov, Sh.Sh. (1977) Materials to the Flora of North-Western Ustyurt. In: Flora and Vegetation of North-Western Ustyurt and Ways to Improve Pastures, Fan, Tashkent, 144.

[23] Shomurodov, Kh., Adilov, B., Rakhimova, T., Rakhimova, N., Aytmurodov, R. and Vokhidov, Yu. (2017) Some Notes on the Key Botanical Territories of Ustyurt (Uzbekistan) and the Influence of Oil and Gas Industries on Them. American Journal of Plant Science, 8, 2811-2824.

[24] Shomurodov, Kh.F. and Saribaeva, S.U. (2014) Effect of Gas Extraction on the State of Euphorbia sclerocyathium Korov.et M.Pop. Population. Journal of Arid Land Studies, 24, 265-268.

[25] Shomurodov, Kh.F., Saribayeva, S.U. and Akhmedov, A. (2015) Distribution Pattern and Modern Status of Rare Plant Species on the Ustyurt Plateau in Uzbekistan. 
Arid Ecosystems, 5, 261-267. https://doi.org/10.1134/S2079096115040125

[26] Dimeyeva, L. (2015) Natural and Anthropogenic Dynamics of Vegetation in the Aral Sea Coast. American Journal of Environmental Protection, 4, 136-142.

[27] Kabulov, S. (1989) Change of Desert Phytocenoses of the Aral Sea in Connection with the Desiccation of the Aral Sea. Dissertation, Institute of Botany, Tashkent.

[28] Rachkovskaya, E.I., Safronova, I.N. and Volkova, E.A. (2003) Botanical Geography of the Desert Area of Kazakhstan and Central Asia. Biol. Inst., St. Petersburg.

[29] Lavrenko, E.M. and Korchagina, A.A. (1964) Field Geobotany. Nauka, Moscow.

[30] Shennikov, A.P. (1964) Introduction to Geobotany. Science, Leningrad.

[31] Drude, P. (1907) Handbuch der Pflanzengeographie. Stuttgart.

[32] Czerepanov, S.K. (1995) Vascular Plants of Russia and Adjacent States (the Former USSR). Cambridge University Press, Cambridge.

[33] Ped, D.A. (1975) About Indicators of a Drought and Excessive Humidification. Proceedings of the Hydrometeorological Center of the USSR, 156, 19-39.

[34] Climate Change (2007) The Physical Science Basis. Contribution of Working Group I to the Fourth Assessment Report of the Intergovernmental Panel on Climate Change. Cambridge University Press, Cambridge and New York.

[35] Ahmad, D.S., Jatna, S., Dedy, D.R., Sutarno, S., Ilyas, N., Wulan, R.K. and Prakash, P. (2017) Impact of Climate Change on Potential Distribution of Xero-Epiphytic Selaginellas (Selaginella involvens and $S$. repanda) in Southeast Asia. Biodiversitas, $18,1680-1695$.

[36] Erin, B., Miguel, V. and Seth, M. (2017) Climate Legacy and Lag Effects on Dryland Plant Communities in the Southwestern U.S. Ecological Indicators, 74, 216-229.

[37] Munson, S.M., Belnap, J. and Okin, G.S. (2011) Responses of Wind Erosion to Climate-Induced Vegetation Changes on the Colorado Plateau. Proceedings of the National Academy of Sciences, 108, 3854-3859. https://doi.org/10.1073/pnas.1014947108

[38] Boote, N.K. (2013) Phenotypic Variation and Invasive Success: A Cros-Continental Comparison of Six Plant Species. University of Montana, Montana.

[39] Birsen, K. (2015) Properties of Types Poa bulbosa L., Bromus tectorum L., Potentill arecta L., Carduus nutans L., Rumex acetosella L. and Hypericum perforatum L. Adnan Menderes University, Aydin.

[40] Blumenthal, D., Chimner, R.A., Welker, J.M. and Morgan, J.A. (2008) Increased Snow Facilitates Plant Invasion in Mixedgrass Prairie. New Phytologist, 179, 440-448. https://doi.org/10.1111/j.1469-8137.2008.02475.x

[41] Hellmann, J.J., Byers, J.E., Bierwagen, B.G. and Dukes, J.S. (2008) Five Potential Consequences of Climate Change for Invasive Species. Conservation Biology, 22, 534-543. https://doi.org/10.1111/j.1523-1739.2008.00951.x

[42] Justin, B.R., Jack, L.B., Megan, M.F., Susan, E.M. and Sharlene, E.S. (2014) Invasive Species and Climate Change. In: Climate Change in Grasslands, Shrublands, and Deserts of the Interior American West, U.S. Department of Agriculture, Forest Service, Rocky Mountain Research Station, Fort Collins, Gen. Tech. Rep. RMRS-GTR-285. 